\title{
微生物による多糖 類の生成
}

\author{
主として応用微生物の立場より
}

\section{原田篤 也 \\ (Tokuya HARADA)}

\section{大阪大学産業科学研究所}

排水処理に使用している砂の層中に“かたまり”がで きることがあり，これは Flavobacterium などの微生物 の生産した多糖類によるものであるといわれている。一 般に, 畑土などには, 微量ではあるが微生物のつくった 多糖類が含まれていて, 土壤の集合の安定性に関与して いるらしい．木の幹の傷口に樹液がかたまっていること が見られるが，そこには多糖類をつくる酵母がほとんど 純粋の状態で生育していることもあるという，砂糖工業 の污染菌として, しばしば多糖類をつくる菌があらわれ ることも古くから知られていた。

さて,このような現象の中から菌が分離され，デキス トランといら多糖類をつくる工業が生まれてきた。第 2 次大戦中，タバコの葉の粉に粘り気を与えるためのグリ セリンが欠乏し，ある粘質物をつくる微生物の培養液が 朝鮮に括いて一部用いられていたが(現 東京教育大学小 林達吉教授の考案), これは今から考えるとデキストラ ンであるらしい. 戦後アメリカの学者によってデキスト ラン工業が成立し，血漿増量剂として用いられているが， 現在では日本でも生産されている.デキストランの研究 の後を追って, アメリカや日本などで, 微生物多糖類を 工業的に生産するための基礎执よび応用的な研究がなさ れてきた，食品添加物，医薬など新しい用途へ活用しよ らといらのである. 寒天やコンニャクのような少し変わ った性質をもった価值の高いものができれば面白いし， ある多糖類の制癌性が問題になっている今日, 癌などに 効力のあるものが登場してくる可能性もみられる.

微生物の生産する特殊な多糖類を工業的に生産しよう という目的以外にも, 微生物工業と微生物多糖類との関 係には種々の問題があるようである. 最近, 清酒のもる みに高泡を生成する協会 7 号酵母が秋山らによって分離 されたが，高泡をつくる原因は，その酵母の生産する細 胞外層多糖類であるマンナンによるといわれている. 清
酒に限らずビールなどでも，酵母のつくる多糖類の製品 に及ぽす影響は種々存在することであろら。

ここでは微生物多糖類の生成の種々な問題をとりあげ るが, 基礎的, 応用的な微生物多糖類の種類や生成 ${ }^{(1 \sim 5)}$, 主として細菌の細胞壁多糖類の生合成 ${ }^{(6)}$, 特殊な応用的 な微生物多糖類 ${ }^{(7,8)}$ などに関しては，それぞれ多くの総 説が発表されている.

\section{I. 多糖類生成の炭素源}

多糖類の生成の機構を考えると，グルコースはまず G-6-P になり, ついで G-1-P に変化し, さらに種々な ヌクレオタイド糖に変化し, このヌクレオタイド糖から 多糖類が生成されてくる，グルコースを炭素源として， 種々異なった構成糖からなる多糖類をつくるためには， グルコースからそれぞれの単糖類のヌクレオタイドがで きなければならない，この場合の代謝の中心となるヌク レオタイド糖は UDPG（ユリジン・ジ燐酸グルュース）. と GDPM (グアニン・ジ燐酸マンノース) とである. 主 な糖のヌクレオタイドの生成 ${ }^{(9)} を$ 示すと次のようになる。

1. UDPG $\longrightarrow$ UDPgalactose,

UDPglucuronic acid $\longrightarrow$ UDPgalacturonic acid UDPN-acetylglucosamine

$\longrightarrow$ UDPN-acetylgalactosamine

2. UDPG $\longrightarrow$ UDPglucuronic acid,

GDPM $\longrightarrow$ GDPmannuronic acid

3. GDPM $\longrightarrow$ GDPfucose,

GDPM $\longrightarrow$ GDPcolitose

TDPG $\longrightarrow$ TDPrhamnose,

4. UDPglucuronic acid $\longrightarrow$ UDPxylose,

UDPgalacturonic acid $\longrightarrow$ UDP-L-arabinose

5. UDP-N-acetylglucosamine

$\longrightarrow$ UDP-N-acetylmuramic acid

グルコース以外の糖を炭素源としても，グルコースを 用いた場合と同様な多糖類ができてくるのが普通で，そ の場合は各糖相互の変化に関する反応が作用している。 
a) 炭素源としてのグルコース

微生物がグルコースを炭素源とした培地で多糖類をつ くるためには，まずグルコースを利用して菌体が増殖し なければならない。すでに増殖した菌体によって多糖類 が生成される場合にも，図1のごとく，たとえば 1 個の グルコース分子が多糖類分子に移行するためには 2 分子 のATPを必要とする。したがって，多糖類をつくるた めには多糖類生合成酵素系と別にエネルギー供給の酵素 系が伴われなければならない，そこで，この両者の酵素

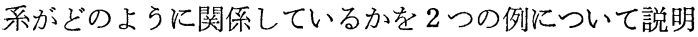
してみよう。

1 つは Neisseria に属する細菌で, ラムノースとグル コース（4:1） とからなる多糖類を生成する場合である (図 2) ${ }^{(10)}$.この菌にはペントースサイクルはなく, グ

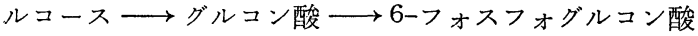
\2-ケトー3-デオキシ-6-フォスフォグルコン酸の経路 を通り，さらにピルビン酸とグリセリンアルデヒド 3 燐 酸とに分解される，いわゆる Entner Doudoroff の代謝 系をもっている。この場合，多糖類はほとんどグリセリ

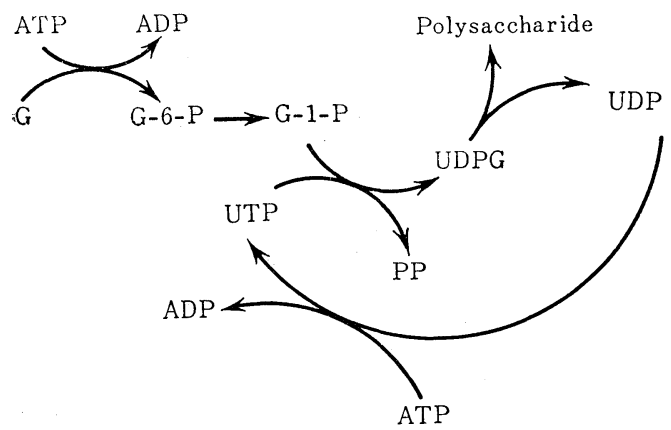

図 1 グルコースの多糖類へのインコーポレー ションの1例

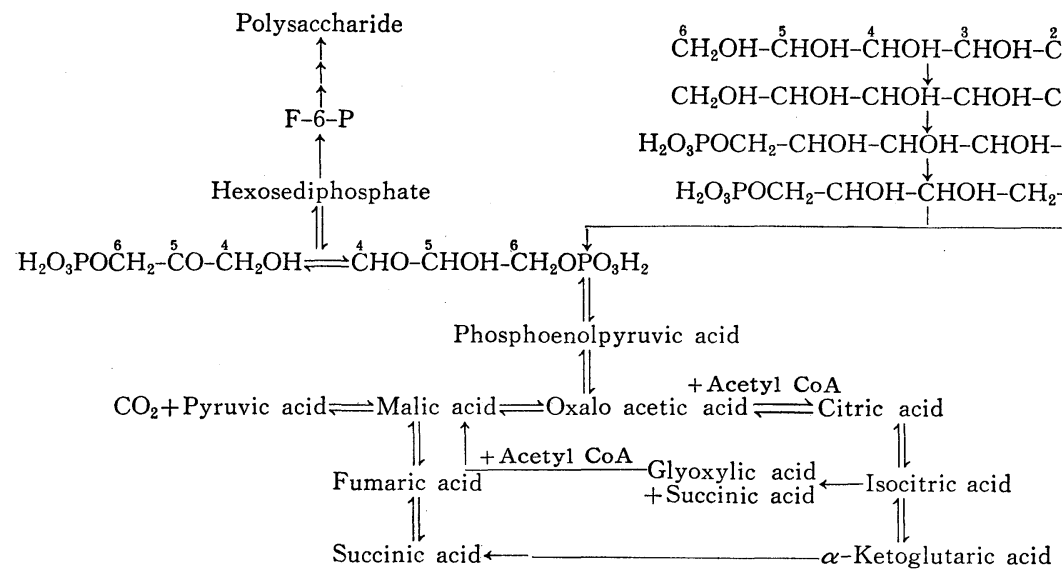

図 2 Neisseria 属細菌によるラムノグルカンの生合成系と末端酸化系 ${ }^{(10)}$
ンアルデヒド 3 燐酸からつくられるので, 種々な炭素の 位置の放射性のグルコースを用いての実験からして， C-4, C-5, C-6 の 75\% は多糖類に移行するが, C-1, C-2, C-3 の場合は $9 \%$ が多糖類に移行するに過ぎない. このように，基質のグルュースの大部分はいったん分解 された後，糖に合成され，さらに多糖類になる。この菌 にはへキソース・ジ憐酸フォスファターゼはあるが，フ オスフォフラクトキナーゼや G-6-P 脱水素酵素はなく， したがって，いったんできたへキソースモノ燐酸の分解 は防げるよらになっていて，多糖類生成のために大変都 合がよい。

もら 1 つの研究は, Acetobacter xylinum の洗浄菌体 によるグルコースからセルロースの生成の場合で(11)， まずグルコースの大部分はグルコン酸に酸化される。グ ルコン酸の大部分は 6-フォスフォグルコン酸になって ペントースサイクルに入り，ペントース燐酸からは F6-Pを通り，さらに G-6-P, G-1-P となり，このものか ら前述のごとく UDPG ができ，さらにセルロースに合 成されるのである、種々な放射性炭素のグルコースを用 いての生合成の実験からわかるように，C-1 からセルロ ースへの移行はごくわずかである.

さて，それでは微生物はグルコースを炭素源とした培 地で多糖類をどの程度までつくりらる能力があるであろ らか.グルコースなどからの多糖類生産量の多い菌株を 表 1 に示した。この数值よりさらに収率を增大しうるも のもあるであろらが，一定培養液中に和ける多糖類の収 率は限度があることが多い，それは，多くの多糖類は粘 性をもっているため培養液が大きなかたまりになり，覺 拌が不充分になり通気ができなくなってしまらためであ って，多糖類の性質上やむをえない場合が多い. 
表 1 数種の菌株による細胞外多糖類の生産

\begin{tabular}{|c|c|c|c|}
\hline 菌 & 棈 成 分 & \begin{tabular}{|l|} 
培地の \\
グルコ \\
ース濃 \\
度(\%)
\end{tabular} & $\begin{array}{l}\text { 生成多糖類 } \\
\text { 添加グルコ } \\
\text { 一ス }(\%)\end{array}$ \\
\hline $\begin{array}{l}\text { Cryptococcus laurentii } \\
\text { NRRL Y-1401(12) }\end{array}$ & $\begin{array}{l}\text { マソノース, キシ } \\
\text { ロース, グルキュ } \\
\text { ロソ酸, グルコニ } \\
\text { ス }\end{array}$ & 5 & 32 \\
\hline $\begin{array}{l}\text { Hansenula holstii } \\
\text { NRRL Y-2408(13) }\end{array}$ & $\begin{array}{l}\text { マソノース, 憐酸 } \\
\text { (フォスフォマンソ } \\
\text { ナソ }\end{array}$ & 5 & 50 \\
\hline $\begin{array}{l}\text { Pullularia pullulans } \\
\text { S-1 }\end{array}$ & $\begin{array}{l}\text { グルュース（プル } \\
\text { ラン) }\end{array}$ & $10^{*}$ & 30 \\
\hline $\begin{array}{l}\text { Xanthomonas campestris } \\
\text { NRRL B-1449(15) }\end{array}$ & $\mid \begin{array}{l}\text { グルコース, マン } \\
\text { ノース, グルキュ } \\
\text { ロソ酸, ピルビン } \\
\text { 酸 }\end{array}$ & 3.3 & 66 \\
\hline $\begin{array}{l}\text { Arthrobacter viscosus } \\
\text { NRRL B-1973(16) }\end{array}$ & $\mid \begin{array}{l}\text { グルュース, ガラ } \\
\text { クトース，ウロン } \\
\text { 酸，酶酸 }\end{array}$ & 2.5 & 44 \\
\hline $\begin{array}{l}\text { Alcaligenes faecalis } \\
\text { var. myxogenes } \\
10 \mathrm{C} 3 \mathrm{M}^{(17)}\end{array}$ & 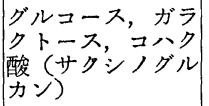 & 4 & 35 \\
\hline $\begin{array}{l}\text { Alcaligenes faecalis } \\
\text { var. myxogenes } \\
10 \mathrm{C} 3 \mathrm{~K}^{(18)}\end{array}$ & $\begin{array}{l}\text { グルコース（カー } \\
\text { ドラン） }\end{array}$ & 4 & 4.5 \\
\hline 有胞子細菌(19) & $\begin{array}{l}\text { グルュース, マソ } \\
\text { ルース, ガラクト } \\
\text { 一ス, グルキュロ } \\
\text { ソ酸 }\end{array}$ & 6 & 30 \\
\hline $\begin{array}{l}\text { Aerobacter sp. } \\
\text { IFO } 12369^{(20)}\end{array}$ & $\begin{array}{l}\text { ガラクトース，マ } \\
\text { ソノース，グルキ } \\
\text { ニロン酸，酢酸， } \\
\text { 高級脂肪酸 }\end{array}$ & $5^{* *}$ & 40 \\
\hline
\end{tabular}

* シュクロースより, ** ガラクトースより.

グルコースからの多糖類生産には，まず培地中の炭素 之窒素の含量の比率が重要で, 窒素含量が高すぎると菌 体の生産のほうが盛んになり，多糖類の生産がわるくな るのが普通である. 次注重要なのは培養中の $\mathrm{pH}$ であっ て, 生育の $\mathrm{pH}$ と多糖類の生産のための $\mathrm{pH}$ とは必ずし も一致するものではなく，培地の組成を適当にすること によって, 発酵中の $\mathrm{pH}$ を一定範囲の $\mathrm{pH}$ に調節させる ことが必要である。

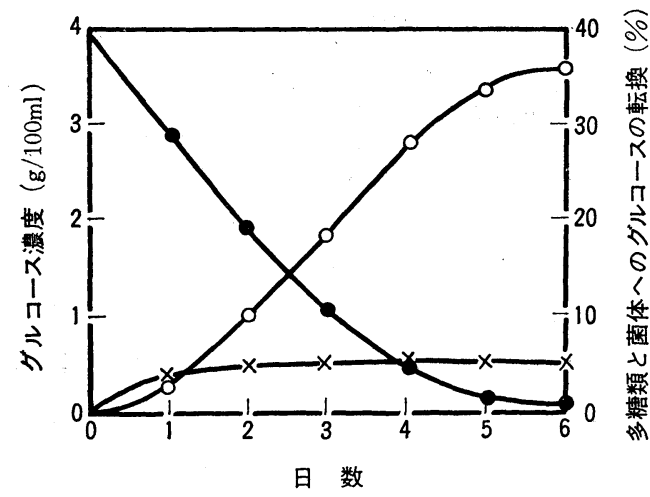

図 3 サクシノグルカンと菌体の生成の経過

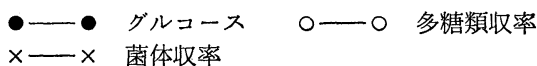
$\times$ ×
多糖類の生産と菌体の生産との関係をサクシノグルカ ン生産菌について見ると，図 3 のごとくになる，菌体の 生産は 1 日培養でほぼ最高に達するが, 多糖類はむしろ 菌体の生産がとまってから後盛んに生産されてくる，乙 たがって，增殖した菌体を集め，この菌体㲘濁液によっ て窒素源などを加えずに多糖類を生産させることもでき る。このような菌体試験によってサクシノグルカンとカ 一ドランを生産する場合, $1 \mathrm{mg}$ 菌体当り（乾燥菌体と して） 1 時間の反応で, 前者は約 $0.087 \mathrm{mg}$, 後者は約 $0.106 \mathrm{mg}$ の多糖類を生産した。 Neisseria のラムノグル カンの場合は約 $0.041 \mathrm{mg}$ である. 実際に培養中では, 生育した菌体（乾燥菌体として）の約 10 倍量のカード ランをつくっている．この菌体懸濁液にクロロマイセチ ンを加えて反応させると，糖は消費されているのに多糖 類が生成されなくなってしまら。この現象はサクシノグ ルカンの生成と E. coli によるグリコーゲンの生成の場 合とに見られ，多糖類生成に関するある酵素の turn over が非常に速いのではないかと考えられている。

\section{b）炭素源としての非炭水化物}

Leuconostoc mesenteroides がデキストランをつくる にはシュクロースが基質として必要であって，デキスト ランシュクラーゼとよぶ唯 1 つの酵素によって, シュク ロースからグルコースの転移作用によりデキストランが つくられる. ラクトースのみからラムノガラクタンがで きるなど，まだ機構の説明しにくい例も知られている。 これに対して，多くの多糖類はグルコースのみならず種 種な糖類からつくられる。ささき述べた Neisseria の場 合においては, グルコースが分解されて 3 炭糖燐酸を経 た後へキッース燐酸が合成され，それから多糖類ができ てくる.このように考元ると，微生物は糖類とは異なっ た化合物，場合によっては炭素 2 わるいは 3 つの種々 な有機化合物，あるいは炭化水素，脂肪酸などからも多 糖類が収率よく生産されてもよいはずである，脂肪酸か らの生成には，まず $\beta$ 酸化を経てアセチル CoA がつぎ つぎと生成し，これがグリオキシル酸サイクルに入り， アセチル CoA 2 分子からコハク酸ができ，これがフォ スフォエノールピルビン酸になり，さらに前述のごとき 経路を経て多糖類に合成されるものと見なされている。

ラムノグルカンをつくる Neisseria の菌株は 2,3-ブ チレングリコールを, サクシノグルカンをつくる Alcaligenes faecalis var. myxogenes $10 \mathrm{C} 3$ はエチレング リコールを，それぞれ唯一の炭素源とした培地で分離さ れた菌株であり，またセルロースを生産しうるAcetobacter xylinum はェタノールを炭素源として酢酸をつ 
くりらる、いわゆる酶酸菌である。これらの菌株はグル コースには劣るものの, ピルビン酸, コハク酸, リンゴ 酸などからも多糖類をつくりらるし，エタノールや眽酸 からもつくる能力がある。サクシノグルカンはエチレン グリコールから $20 \%$ 程度の収率でつくられる。な拉，種 種なグルコース以外の糖, 非炭水化物の化合物を炭素源 とした場合に秃いても, 生成されてくる多糖類の構造は, 一般的にはグルコースからできる多糖類と同じものであ る。最近, 協和醊酵工業株式会社で, Arthrobacter parafjineus No. 2411 が $\mathrm{C}_{12} \sim \mathrm{C}_{18}$ の nーパラフィン混合物か ら $1 l$ 中約 8 $10 \mathrm{~g}$ の糖を生成し，その 70〜80\% はト レハロースであることが報告されたが，今後は非炭水化 物資源から多糖類以外の種々な糖類か生産されることも 報告されるであろう。

\section{II. 多糖類中のグルコサイド結合などの生成機構}

\section{a) ホモ多糖類中の直鎖のグルコサイド結合の生成}

植物に执いては，七ルロースでは GDPG あるいは $\mathrm{UD}=\mathrm{G}$, アミロースでは ADPG, $\beta-1,3$ 結合から主と してなるカロースでは UDPG と，それぞれ異なった糖 ヌクレオタイドからつくられる。これらの生体内に和け る役割が異なっているので, 糖供与体としての糖ヌクレ オタイドが異なっていることは大変都合よく, 多糖類生 成つ調節がこの段階でなされているのである。微生物に おいては, 貯蔵物質としての細胞内のグリコーゲンは植 物のデンプンと同じょらに ADPG からつくられる。. $E$. coli の UDPG を合成でさない変異株でも, 親株のつく るグリコーゲンと同じもの，しかも量的には親株よりも 多量沉くることから考えて, グリコーゲンが ADPG よりつくられることは明らかである。また, 細菌にはグ リコーゲン生成系の ADPG ピロフォスフォリラーゼ, ADPG グリコーダントランスグリコシラーゼが広く分 布している．植物のセルロースとほとんど同じものが， ある酶酸菌やSarcina の菌株によってつくられ，この場 合にはUDPG が用いられるが，GDPG も効果があると いわれて拉り，植物の場合と似ている。ささらに，グルコ 一スのみからなる微生物の多糖類に $\beta-1,2$ グルカンと $\beta-1,3$ グルカンとが知られている. 前者は Rhizobium japonicum, Agronobacter に上り細胞外につくら方多 糖類であり, UDPG からつくられる。 $\beta-1,3$ のグルコ サイド結合を $99 \%$ 以上含息多桔垁としては細菌のつく るカードランが知られているが, その生合成の機構につ いてはわかっていない. 鞭毛虫類である Euglena gracilis は細胞内に顆粒として paramylon とよぶ $\beta-1,3$
グルカンをつくるが，このものは UDPG からつくられ る.

プルランは Pullularia pullulans とよぶ酵母のつく るもので, $\longrightarrow \rightarrow{ }_{4} \mathrm{G}_{1} \longrightarrow{ }_{6} \mathrm{G}_{1} \longrightarrow{ }_{4} \mathrm{G}_{1}-\rightarrow$ のごとく $\alpha-1,4$ の結合が 2 つ付き, その次に $\alpha-1,6$ の絬合が 1 つ付い た単位からなるグルコースの直鎖状の多糖類である。= ゲランは Aspergillus niger のつくる多桾類で, $\alpha-1,3$ と $\alpha-1,4$ のグルコサイド結合が交互に存在する直鎖の 多糖類である。サクシノグルカンは Alcaligenes faecalis var. myxogenes $10 \mathrm{C} 3$ のつくる細胞外の多糖類で, $\beta-1,3, \beta-1,4, \beta-1,6$ の結合が約 $65: 25: 10$ の割合 で存在する, 主としてグルコースの直鎖状の多糖類であ り, 糖のCの 6 の位置にコハク酸のカルボキシル基の 1 つがエステル状に結合している（糖 5 個にコハク酸 1 個 の割合).このように，異なったグルコサイド結合の直鎖 状になった多糖類の生合成の機構についてはまだ研究さ れていないようで，それぞれ異なった結合をつくる酵素 が別々にあるのか，1つの酵素が異なったグルコサイド 結合をもつくるのかなど，興味がもたれている．

\section{b ） ホモ多糖類中のグルコサイド鎖分汥の生成}

グリコーゲンやアミロペクチンの枝分かれをつくる酵 素は Branching enzyme あるいはQ酵素とよばれ，肝 蔵や豆で，また酵母やArthrobacter で研究され，酵母 の酵素は動物や植物のものより広い特異性をもつといわ れている. amylose $\longrightarrow$ amylopectin type $\longrightarrow$ glycogen type と 2 段階を経る。 その機構は肝臓の酵素について よく研究されており, ある長さの $\alpha-1,4$ のグルコサイ ド鎖が切れ，転移作用によって $1 \longrightarrow 4$ から $1 \longrightarrow 6$ 鎖 をつくり枝分かれができる，微生物の多糖類で側鎖をつ くるものは非常に多く，たと究ば，酵母の細胞壁の $\beta$ 1,3 グルカンやマンナンは, いずれも $\beta-1,6$ 結合の直鎖 飞, 前者は $\beta-1,3$, 後者は $\beta-1,2$ と $\beta-1,3$ の結合で側 鎖が多数付いている.この場合，1つの酵素が主鎖を つくり，他の酵素が $1 \longrightarrow 2,1 \longrightarrow 3$ の側鎖をつくるの か, $1 \longrightarrow 2,1 \longrightarrow 3$ の適当な長さの単位をつくり, こ れらが $1 \longrightarrow 6$ の結合からなるプライマーに付くのかな どまったくわかっていない、デンプンやセルロースな どの生合成の場合においてもプライマーの問題が種々論 議されているが，プライマーの構造がでさてくる多桾類 の構造をも決めることになるのであろうか．多糖類がつ ぎつぎと新生していくためには，他方，プライマーが新 しく生成してくる機構がなければならない.

Saccharomyces carlsbergensis では, マンナンは GDPM からつくられる。側鎖をつくるのではないが， 
Corynebacterium ではやや不可解な現象が知られている. それは，C.triticiなどが天然のデンプンを炭素源として 生育したときにのみ細胞内にデンプン様物質を生成する ことであって, 基質デンプンがなくなり還元性糖が出て こないで細胞内にデンプンが出現することから，おそら くデンプンの鎖の端からグルコースあるいは他のフラグ メントが細胞内に移行し, 新しいデンプン分子がつくら れたものであろら。この場合，アミロースからアミロー スができるのである．これに似た酵素としては，ジャガ イモから得られた D-酵素, またマルトースからアミロ 一スをつく E. coli のある菌株の生産するアミロマル ターゼ，B. macerans のつくる特殊なアミラーゼなどが ある。

c) ヘテロ多糖類の巽なった単糖類のクルコサイド 結合の生成

微生物の多糖類の棈成糖としては, グルコース, マン ノース, ガラクトース, キシロース, フコース, ラムノ 一ス,グルキュロソ酸, ガラクチュロン酸, マンニュロ ン酸などが一般に知られており，それぞれの糖に相当し た UDPG, GDPG, GDPM, UDPGal, UDPXyl, UDPFuc, UDPRham, dTDPRham, UDPGluc, UDPGalac, GDPMannur などが微生物に見いだされ，またこれらの糖ヌ クレオタイドを生成する酵素も知られている。さらに, 微生物の種々な細胞壁多糖類などの特殊な構成糖のヌク レオタイドも知られている. マンノースとキシロースと グルキュロン酸とからなる多糖類をつくるCryptococcus laurentii NRRL Y-1401 の培養液からは UDPG, GDPM, UDPXyl が分離され, UDPGluc から UDPXyl をつくるUDPGluc 脱炭酸酵素も見いだされている。ま た, Arthrobacter sp. NRRL B-1973 はグルュース, ガ ラクトース，マンニュロン酸 $(1: 1: 1)$, アセチル基 $25 \%$ からなる $\beta$-結合の多糖類をつくるが, この菌から は GDPM をつくる酵素とともに GDPM を GDPMannur にする酵素が見いだされている.また多くのカビは キチン様の多糖類をつくるが，Neurospora crassa は UDP-N-アセチルグルコサミンからキチンをつくること ができる。

さて, このようにして, へテロ多糖類の生成には, ま ずそれぞれの単糖類に相当した糖ヌクレオタイドができ， それから多糖類がつくられるのである。この場合, はじ めに単位となるようなオリゴ糖ができ，オリゴ糖どうし が結合し多糖類になるのか，順次 1 つずつ単糖類が付き 分子が大きくなって多糖類に生長するのかなど, 種々な 機構が考えられる.しかし，細胞外につくられるへテロ
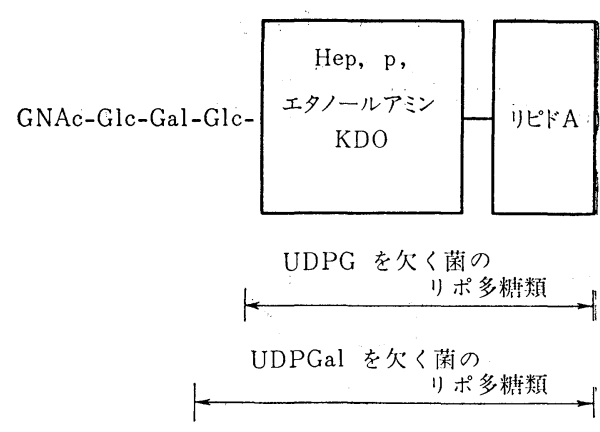

図 4 無細胞系での生合成の実験から推定された R-core の構造 ${ }^{(21)}$

多糖類の生合成についてはまだ研究されていないＳＳｌ一 monella などの菌体の表面に存在するリポ多糖類の生合 成については，その構造の複雑さにかかわらず，かなり よくわかってきている.この点についてはすぐれた総 説 ${ }^{(21)}$ があるので, この表題に関寸る重要な点だけを簡単 に述べる.

このリポ多糖類は多くの一般的な糖のほかに特殊な糖 によって構成されている。すなわち, KDO (3-deoxyclulosonic acid, 8 炭糖) や; 3,6-デオキシヘキソース であるアベュース, チベロース，コリース，アスカリ ロースなどが見いだされている，UDPGをつくれない 変異株であるとグルコースから先の部分ができないし， UDPGal をつくれない変異株の場合はガラクトースから 先の部分ができない（図 4). 結局, Glc, Gal, Glc, GNAc と糖が 1つずつそれぞれの糖ヌクレオタイドから逐次加 えられ，つくられていくことになる.ところが, core の 先に付くべき糖の場合には，たとえば R-core のすぐ隣 りの糖, ガラクトースのそれに相当する UDPGal がで きたとしても，その先の糖の生成酵素系が欠けていれば R-core にガラクトースは付かない. Salmonella の無細 胞酵素系に 0 側鎖に存在する 3 つ糖, ガラクトース, マンノース, ラムノースを同時に糖ヌクレオタイドとし て与えれば，リポ多糖類と結合した形で 0 側鎖が合成さ れる.ところが，1つでも欠けるとリポ多糖類にほとん， ぞ糖が結合してこない，この場合は1つずつ糖が付いて いく機構ではないので, 次の項で, その機構について述 ベる.

\section{d）多糖類生合成中間物質としてのリピド}

Colvin ${ }^{(22)}$ は眽酸菌および高等植物のセルロース生合 成の中間物質としてリピドの存在を唱えたが, リピド中 間説を考えると, 細胞内で糖ヌクレオタイドができ，こ れが細胞壁中のリピドと結びつき, 細胞壁を通過し, 細 胞の表層に出て，そこでセルロースが合成されるという 


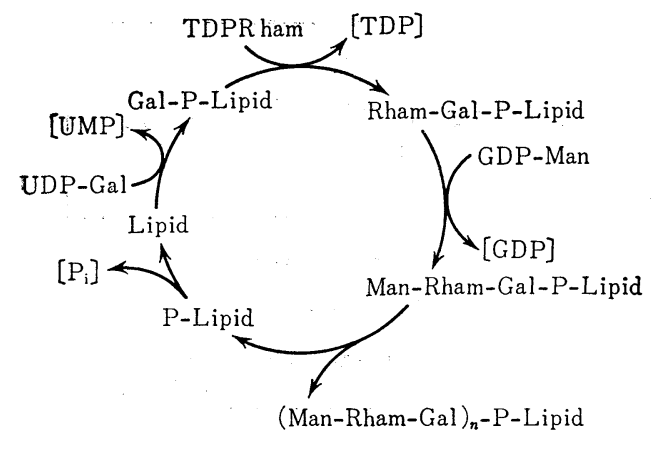

(Man-Rham-Gal) $n$-Man-Rham-Gal-P-Lipid

$$
\begin{aligned}
& \text { Complete Lipopolysaccharide } \\
& \text { CDP-Ab }
\end{aligned}
$$

図 5 Salmonella の 0 側鎖の生合成の機構 ${ }^{(23)}$

ことで大変理解されやすい...Staphylococcus aureus の 細胞壁のペプタイドグリカンの生合成にも，リピドが中 間物質炕なることが考えられている。また，Diplococcus pneumoniae Type XIV の顆粒の標品が抗原多糖類と同

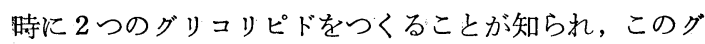
リコリピドがやはり多糖類生合成の中間物質になるので はないかと考えられている。しかし，リピドが多糖類生 成の中間体となることが明確にされたのは，さきに述べ たリポ多糖類の O 側鎖の生合成機構においてである.図 5 に示されるごとく(23)，ガラクトース，ラムノース，マ ンノースは直接 core に1つずつ結合していくのではな く, 各糖ヌクレオタイドからそれぞれの糖がリピドに 1

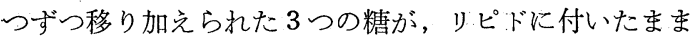
ポリメライズされ，そのポリメライズされたものが $\mathrm{R}-$ core に転移するのである。そのリピドの構造も明らか にされている(24).

\section{e）糖と糖でない化合物との結合生成}

微生物の多糖類には, 糖以外に燐酸, 酢酸, コハク酸, マロン酸, 高級の脂肪酸などがェズテルとして結び付い ているものが知られている。蛋白質やペプタイド，リピ ドが付いたものも知られているが，細胞外多糖類として 集積することは普通には見られないので，ここではふれ ないことにする，ただ，E. coli のリジン要求株がリジ ンの制限培地でリポ多糖類を細胞外に蓄積することが観 察されている。海藻には寒天, カラゲナンなどの硫酸エ ステルの多糖類が，また動物の軟骨などにはコンドロイ チン硫酸などが含まれているが，微生物にはいまだ硫酸 多糖類は知られていない.

エノールピルビン酸を 2-フォスフォエノールピルビ
ン酸から UDPGlcNAc 中のア七チルグルコサミンの 3 の位置に酵素的に転移することが E. coli などに見いだ され，この生成物はさらに変化してミュラミン酸になる。 Hansenula capsulata NRRL Y-1842, Hansenula holstii NRRL Y-2448 のつくる細胞外多糖類であるフォス フォマンナンは, マンノースのヘミアセタールのハイド ロキシ基と他のマンノースの $\mathrm{C}_{6}$ のハイドロキシル基と の間に燐酸のジェステルの結合をなしている。フォスフ オガラクタンは Sporoboromyces sp. NRRL Y-2493 に よってつくられるが，いずれも生合成の研究はなされて いない、燐酸のジェステルで結合している多糖類として は,グラム陽性菌の細胞壁に存在している teichoic acid, すなわちポリグリセロ燐酸とポリリビトル粼酸とが知ら れているが, このものについては活発な研究がなされて いる. 多糖類中の有機酸エステルのできる機構について は研究されていない. 単糖類に有機酸が先に結合するの か, オリゴ糖が先にできて，これに有機酸がエステルと して結合するのかなど，いまだ不明である。

\section{III. 多糖類生成の調節}

微生物は一般に, 培地に多量のグルコースが存在する 場合には細胞内にグリコーゲンのような貯蔵多糖類をつ くる。また, 細胞壁には微生物の種類に応じて種々な多 糖類が含まれており，細胞の増殖に伴って細胞の構成分 として生成されてくる．E. coli の細胞壁の構成糖であ るラムノースのヌクレオタイド TDPRham は TDPG か らつくられるが, TDPRham によって TDPGを生成す る酵素 TDPG ピロフォスフォリラーゼが阻害される. このような機構によって, 必要以上にラムノ一スが生成 されないように調節されている.これに対して, 前述し たごとく，ある微生物ではグルコースなどが培地に多量 に含まれていると, その微生物に特有な多糖類を細胞外 に多量に生成蓄積する。このような多糖類を微生物はな んのためにつくるのかは，種々推測はできるものの，明 確な解答を与えることはむずかしいようである。ただ， このよらな多糖類の中には私たちの生活に役立つものが あるように思えるし，またグルコースなどからの収率も よいので，さらにそれらの多糖類生成の調節機構をさぐ り, その機構を応用して新しい多糖類生産の方式を考兄 ていきたい.

\section{グリコーゲン生成の調節}

動物においてはグリコーゲンの生成および分解の調節 機構が巧みになされており，それによって血糖の值が正 常に保たれていることがよく知られている。これに対し 
て，植物におけるデンプンの生成と分解の調節機構にお いては, ホウレン草のクロロプラスト中の ADPG ピロ フォスフォリラーゼが，3-PGA，PEP，F-D-P など解糖 系の中間代謝物質によって著しい促進効果をらける。こ れと同様な調節機構は，微生物においてすでに知られて いた(25)，すなわち, Arthrobacter, Rhodospirillum rub. rum, Agrobacterium tumefaciens の ADPG ピロフォ スフォリラーゼは F-6-P, ピルビン酸, R-5-P, G-6-P

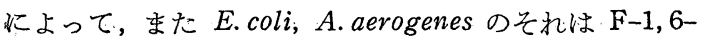
$\mathrm{P}$, グリセリンアルデヒド-3-P, フォスフォエノールピ ルビン酸によって, それぞれ活性化される. 解糖系の酵 素が活発に働き，その中間代謝物質の量が増大すると， その影響をらけて ADPG の合成が活発になり, 終局は グリコーゲンの生成が増大するしくみである。この場合, $\mathrm{ADPG}$ からグリコーゲンをつくるグリコーゲンのトラ ンスグリコシラーゼの作用は，これらの中間代謝物質に よって影響されない.

\section{IV. 多糖類の生成に関する変異}

多糖類の生成に関して古くから多くの細菌について知

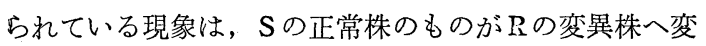
異することであって, dissociation とよばれ, 細胞壁あ るいはカプセルの多糖類に関しての変異である。液体培 地では， S 株は一様に混濁してくるが， R株ではかたま って沈澱するなどの差が見られる：このよらな変異に注 目して, Salmonella などの細胞壁の多糖類生成に関し ての変異株が多数とられ, そのリポ多糖類の生成機構, 構造などが明らかにされてきた。ささに Pneumococcus の多糖類, Xanthomonas のエンドトキシンのヘテロ多 糖類の構造, 生成機構に関しても, 変異株を用いての研 究が大いに役立っている.

Acetobacter xylinum によるセルロースの生成に関し

\section{表 2 Alcaligenes faecalis var. myxogenes} の種々な変異株によるサクシノグルカンとカ 一ドランの生成 ${ }^{(26)}$

\begin{tabular}{|c|c|c|c|c|}
\hline 菌 株 & $\begin{array}{l}\text { サクシノグ } \\
\text { ルカソの生 } \\
\text { 成量 } \\
(\mathrm{mg} / 100 \mathrm{ml})\end{array}$ & $\begin{array}{l}\text { カードラン } \\
\text { の生成量 } \\
(\mathrm{mg} / 100 \mathrm{ml})\end{array}$ & $\begin{array}{l}\text { 乾燥菌体 } \\
\text { 生成量 } \\
(\mathrm{mg} / 100 \mathrm{ml})\end{array}$ & \begin{tabular}{|} 
糖の消費率 \\
利用された糖 \\
添加した糖 \\
\end{tabular} \\
\hline 親 株 $\mathrm{M}$ & 1,670 & 390 & 174 & 100 \\
\hline 変異株22 & 1,970 & 14 & 108 & 100 \\
\hline " 53 & 740 & 840 & 101 & 88 \\
\hline$=25$ & 550 & 1,840 & 125 & 100 \\
\hline " 29 & 90 & 2,400 & 128 & 100 \\
\hline$=\mathrm{K}$ & 0 & 2,050 & 179 & 100 \\
\hline " 11 & 0 & 590 & 122 & 72 \\
\hline " 60 & 0 & 580 & 150 & 70 \\
\hline " 71 & 130 & 0 & 72 & 18 \\
\hline
\end{tabular}

Vol. 6 , No. 12
ても, セルロース生成能のない変異株が数多く知られて おり,それらの変異株はまた他の生理的性質においても 非常に異なっていたりするが，この変異株を用いての生 化学的な研究はなされていない.Alcaligenes faecalis var. myxogenes $10 \mathrm{C} 3$ の多糖類生成に関しての変異株 は, ニトロソグアニジン処理をした後，コロニーの外観 的な相違によって得られた，それらの変異株には，表 2 のごとく(26), サクシノグルカンをつくらなくなりカード ランのみをつくるもの, カードランをほとんどつくらな くなったもの，その活か中間的な変異株が得られている. カードランは 99\% 以上 $\beta-1,3$ のグルコサイド結合か らなる直鎖の多糖類であり, サクシノグルカンは前記の ごとく $\beta-1,3$ と $\beta-1,4$ と少量の $\beta-1,6$ のグルコサイ ド結合をもった直鎖の多糖類で，コハク酸を約 $10 \%$ 含 んでいる. したがって, カードランはサクシノグルカン から単にコハク酸がとれたという多糖類ではないので, これらの変異株によるサクシノグルカンとカードランの 生成機構, またとの調節機構を, 遺伝生化学的に明らか にすることに興味がもたれている。変異株Kは長くェチ レングリコールの培地で培養保存をつづけた結果得られ た変異株であり, Acetobacter xylinum のセルロース生 成に関する変異株が容易に自然に得られた事実などとあ わせ考えると, 多糖類生成に関しての変異株は一般にか なり容易に得られるもののようである．結局，そのよう な多糖類の生成は微生物自体の生死とはあまり関係がな いためであろう。しかし，私たちが種々な多糖類を役立 たせていこうとする場合に，変異によって親株とは異な った種々な多糖類を生産する可能性が考えられることは 重要かつ興味あることである．粘稠な酸性多糖類である サクシノグルカンを多量につくる親株が変異によってそ の多糖類をつくらなくなり，加熱するとかたまるコンニ ヤクあるいは寒天にも似た中性多糖類カードランをつく るようになったことは, 将来の多糖類の生産研究に新し い方向を与えるものと考える。

今まで述べてきたように，微生物の多糖類の生成機構 について詳しく研究されているのは, 細胞外に多量につ くられる多糖類についてではなく, 細胞壁あるいは菌体 表面に存在する多糖類についてである。このような多糖 類は免疫と関係があり, 医学者や生化学者の研究対象と なっている。また, 応用微生物学者にとっては, 培養液 中に多量に生産される多糖類か, なんらかの生理作用を もった多糖類に, より多くの興味がひかれるのである。

多糖類の有機化学的な構造研究は, セルロース, デン 
プン,グリコーダンから始まり, '種々な植物の多糖類, 最近では動物のグリコペプタイド，グリコプロテイン， グリコリピドなどが盛んに研究されている，これらの多 糖類の研究る, 単に有機化学的な手法の久では有機化学 的な構造を知ることすら困難で, 生理学的に, 生化学的 に, その多糖類の生合成や特殊な酵素に上る分解などに 関しての知見が得られなければならない，有機化学，生 化学, 遗伝学, 生理学, あるいは栄養学, 薬学, 食品学 の多方面より多糖類を総合的に研究していくことによっ て，新しい未知の問題が数多くうまれてくるものと思う． こうした微生物多糖類の総合的な研究は, 単に応用面に 新しい発展の可能性を与えるのみでなく, 多糖類の基礎 研究にも大きな貢献をしていくことであろう。

\section{文献}

1）原田篤也：酶工，42，644 (1964).

2) 原田篤也：酹酵協会誌，23，440 (1965).

3). 三崎旭：高分子, 17, 569 (1968).

4) R.F.Anderson: "Biochemistry of Industrial Microorganisms", ed. by C. Rainbow \& A. H. Rose, Academic Press, 1963, p. 300.

5) N. Sharon: Annual Review of Biochem., 35, 485(1966).

6) B. L. Horecker : Annual Review of Microbiol., 20, 253 (1966).

7) 原田篤也：高分子, 16, 1197 (1967).

8) 藤原脩雄, 篠田晃: 高分子, 16, 1192 (1967).

9) V. Ginsburg: Advan. Enzymol., 26, 35 (1964).

10) W. H. Taylor and E. Juni : J. Bact., 81, 694 (1961).

11) M. Schramm, Z. Gromet and S. Hestrin : Nature, 179, 28 (1957).

12) M. C. Cadmus, A. A. Lagoda and R. F. Anderson : Appl. Microbiol., 10, 153 (1962).

13) R.F.Anderson, M.C. Cadmus, R. G. Benedict and M. E. Slodki : Arch. Biochem. Biophys., 89, 289(1960).

14) S. Ueda, K. Fujita, K. Komatsu and Z. Nakashima: Appl.Microbiol., 11, 211 (1963).

15) S. P. Rogovin, R.E. Anderson and M. C. Cadmus : Biochem. Microbiol. Technol. \& Eng., 3, 51 (1961).

16) M. C. Cadmus, H. Yasdorf, A. A. Lagoda, R. F. Anderson and R.W. Jackson : Appl. Microbiol., 11, 488 (1963).

17) T. Harada, T. Yoshimura, H. Hidaka and A. Koreeda : Agr. Biol. Chem., 29, 757 (1965).

18) T. Harada, K. Fujimori, S. Hirose and M. Masada: Agr. Biol.Chem., 30, 764 (1966).

19）二宮英治，木崎忠重，花田香一：譨化，42，178 (1968).

20）三崎旭，金丸志津子，磯野正雄 : 生化，39，542 (1967).

21）二階堂博: 蛋白質 核酸 酵素, 12, 1446 (1967).

22). J. R. Colvin : Can.J. Biochem. Physiol., 32, 1921(1961).

23) M. Dankert, A. Wright, W. S. Kelley and P. W. Robbins : Arch. Biochem. Biophys., 116, 425 (1966).

24) A. Wright, M. Dankert, P. Fennessey and P. W. Robbins : Proc. Nat. Acad.Sci., 57, 1798 (1967).

25) L. Shen and J. Preiss : Biochim. Biophys. Res. Com mun., 17, 424 (1964).

26) T. Harada, A. Amemura, H. Saito, S. Kanamaru and A. Misaki : J.Fẹment. Technol., 46, 679 (1968).
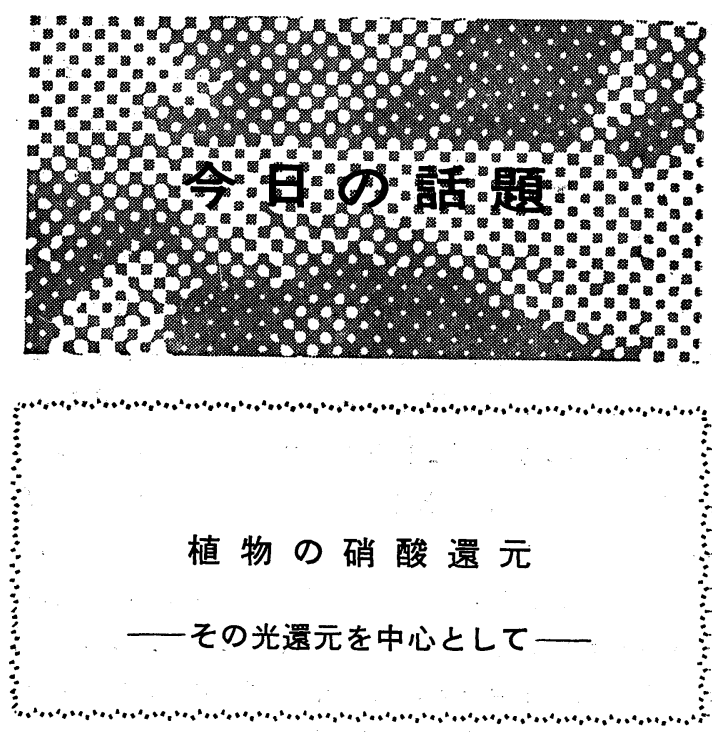

いうまでもなく，人間を含めたすべての動物の食物の ほとんど全部は, 直接間接に緑葉の営む光合成反応によ って生産されたものにほかならない，植物の根によって 吸収された硝酸も, たいていの場合，その大部分はその ままの形態で合成反応の場である緑葉に移行され，そこ で還元されてアンモニアとなり,さらにアミノ酸, 蛋白 質へと同化されるのであるが，ここでは硝酸還元を広義 に解釈し; 文字どおりの硝酸の還元と，その生成物であ る亜硝酸の還元の両過程について，とくにその光合成的 還元を中心に, 最近の話題をひろってみたい.

硝酸還元反応は，次のような反応より成り立っている。 まず，硝酸は硝酸還元酵素の助けをかりて還元物質より 水素をもらい, 自身は亜硝酸となる。この亜硝酸はさら 飞亜硝酸還元酵素の助けをかりて還元物質上り水素をも らい, 最終的にはアンモニアとなる。それでは，両還元 反応の還元物質とは一体何であろらか、緑葉から精製さ れた硝酸還元酵素に対する水素供与体としては, 現在の, ところ $\mathrm{NADH}, \mathrm{NADPH}, \mathrm{FADH}_{2}, \mathrm{FMNH}_{2}$ のほかに, 人工的な viologen 色素の還元型があげられている.こ こにあげた生理的な補酵素は植物体内の各種異化的代謝 反応において生成されるが，これらの還元補酵素生成反 応と硝酸還元反応とが共役したときに硝酸が還元されう る。しかし，どのような異化的還元補酵素生成反応之共 役しているかは, 現在のところ何も知られていない，1 つの確かな共役反応は, 光合成電子伝達系に上り生成さ れる NADPH が大豆葉から精製された硝酸還元酵素と の共同作用で硝酸を還元するという反応である．この発 見（1953）は還元力を光合成電子伝達系に求める契機上 なり、その後活発な研究が行なわれた。その結果, 大豆 